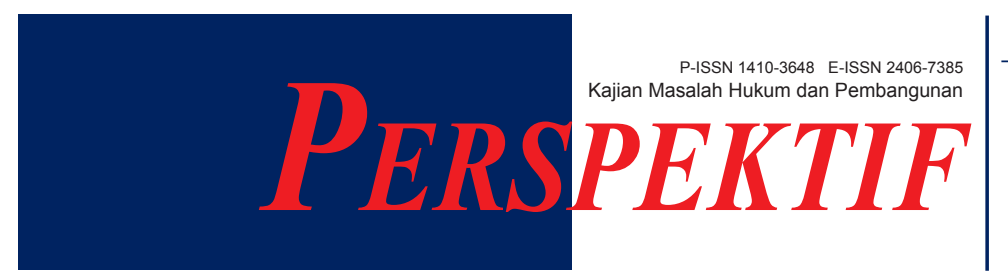

\title{
DUALISM ON TYPE OF LAWSUIT AND PROCEDURE LAW IN THE PERSPECTIVE OF LAND PROCUREMENT/ ACQUISITION DISPUTES FOR PUBLIC INTERESTS
}

\author{
Alifin Nurahmana Wanda \\ a Prosecutor at Kejaksaan Negeri Gresik \\ e-mail:alif_bemper2@yahoo.co.id
}

\begin{abstract}
The existence of the principle as well as the norm that the judge/court must not reject the case (ius curia novit), it turned out to be an interesting discussion in the discourse regarding land procurement/ acquisition disputes for public interests, which have been known together that the arrangements regarding the procedure for settlement, land procurement/acquisition disputes for public interests is regulated separately outside the BW and HIR/RIB, namely by law of RI No.2 of 2012. So in a land procurement/ acquisition dispute for public interests, in the name of the principle and norm of ius curia novit, is it still possible to file a lawsuit in violation of law through mechanisms and procedures as regulated by BW (material civil) and HIR/RIB (formal civil), and therefore there is no need to submit to the provisions of the Law of RI (UU RI) No. 2 of 2012 or in other wise it means crashing into the norm preference principle namely lex specialis derogat legi generali? Though both of these principles are the same position and degree. To answer that question, each description will be discussed about the concept of the two principles from the viewpoint of legal theory, then later it will be described which concept is more relevant to the benefit and law enforcement based on rational legal arguments, so as to create legal certainty, justice, and legal usefulness in resolving land acquisition disputes in the public interests in Indonesia.
\end{abstract}

Keywords: procedure; lawsuit; dispute; land procurement/acquisition for public interests

\section{PRELIMINARY}

Basically, regarding absolute competence speciallize in the civil justice regime, the authority to adjudicate cases of lawlessness (onrechtmatigedaad) absolutely becomes one of the duties and functions of the General Court where the judge/court must not refuse to examine, try and decide upon a case filed under the pretext that the law is absent or unclear, but it is obligatory to examine and try the case (Pasal 16 Undang-undang RI Nomor 48 Tahun 2009 tentang Perubahan Atas Undang-Undang RI Nomor 4 Tahun 2004 tentang Kekuasaan Kehakiman)

But it becomes an issue where justice seekers claim their rights to God's representatives (refers to Judge) regarding disputes which in fact the legal procedure has been regulated separately in a law even by the derivative rules below, but they feel that they don't get justice that deserves these special regulations so try to experiment with a legal breakthrough.

Based on legal understanding with juridical normative aspect, in a land acquisition dispute for the public interests between the Plaintiff/Litigant (the legal standing usually owned by the land owner) and the Defendant (the legal standing usually owned by the Government), there is no regulation that prohibits the Plaintiff from submitting an ordinary lawsuit/conventionally by applying the argument in article $1365 \mathrm{BW}$ so that automatically must follow procedural law that generally refers to the provisions of HIR/RIB (Het Herzein Indonesisch Reglement Stb. 1848 No. 16 Jo Stb. 1941 No. 44), as well as several other relevant laws and regulations governing civil procedural law procedures in general such as $\mathrm{RBg}$ (Rechtsreglement voor de Buitengewesten, 
Alifin Nurahmana Wanda, Dualism on Type of Lawsuit and Procedure Law

in The Perspective of Land Procurement/Acquisition Dispute For Public Interests

Staatsblad 1927 Number 227), Rv (Reglement op de rechtsvordering, Staatsblad 1847 Number 52 juncto 1849 Number 63), RO (Staatsblad 1927 Number 227), $\mathrm{Rv}$ (Reglement op de rechtsvordering, Staatsblad 1847 Number 52 juncto 1849 Number 63), RO (Staatsblad 1927 Number 227), Rv (Reglement op de rechtsvordering, Staatsblad 1847 Number 52 juncto 1849 Number 63), RO (Staatsblad 1927 Number 227) Reglement of de rechterlijke organisatie in het beleid der justitie in Indonesia, Staatblad 1847 Number 23), BW (Burgerlijk wetboek/Civil Code/Code of Civil Law) which was codified on May 1, 1848), KUHD/ Code of Law The Commercial Law Act (Wetboek van Koophandel, 1st book of the Republic of Indonesia State Gazette Number 276 which came into force on July 17, 1938 and the second book of the Republic of Indonesia State Gazette Number 49 of 1933). As for the aspects of proof for the Indonesian nation, the arrangements have been included in H.I.R which contains the procedural law in force in the District Court. ${ }^{1}$ The juridical consequence of the application of procedural law based on HIR/RIB as well as several laws and regulations will automatically override the more specific procedural law provisions as regulated in UU RI No. 2 of 2012 concerning Land Procurement for Public Interests Jo. Peraturan Mahkamah Agung (PERMA) Number 3 of 2016 concerning Procedures for Submitting Objection and Custody of Compensation to the District Court in Land Procurement for Development in the Public Interests.

For case example by decision of the Supreme Court of the Republic of Indonesia (Mahkamah Agung RI/MA RI) Number: 2597K/Pdt/2018 dated September 20, 2018, with the following brief position case: PT. Platinum Ceramics Industry as the land owner who requested an appeal (formerly the plaintiff), with the construction of the KLB toll road in early 2017, the compensation value for land and buildings owned by PT Platinum is in the amount of Rp.1,042,196, - (one million forty-two thousand one hundred ninety six rupiah) has been determined by the Head of the Land Office of Gresik Regency as the Respondent II (formerly Defendant II) on June 21, 2016 and on September 21, 2016 at the Village Hall of Lebaniwaras, Wringinom Sub-District accompanied by the Minutes of Deliberation with the owners of the Deliberation II land including the Plaintiff. However, the Plaintiff argued and proved in court that during the deliberation process he never agreed to sign the agreement because there

${ }^{1}$ Subekti. (1996). Pokok-Pokok Hukum Perdata. Jakarta: PT Intermasa, h. 176 was no common ground regarding the value of compensation for the Plaintiff's HGB land included in the project's Location Determination map. Furthermore, the Plaintiff filed a Lawsuit for Violating Laws with a Lawsuit dated May 22, 2017 and was registered in the Registrar's Office No. Gresik District Court. Register 35/Pdt.G/2017/PN.Gsk, the lawsuit is addressed to:

1. Government of the Republic of Indonesia qq Minister of Public Works and Public Housing of the Republic of Indonesia qq Director General of Highways qq Chairman of the Krian-Legundi-Bunder Toll Road Procurement Team, having its address at: Green Garden Regency Housing Block D6 No. 21 Gresik, Telp/Fax: 031-99103593, referred to as Defendant I;

2. Government of the Republic of Indonesia qq Minister of Home Affairs qq Head of National Land Agency of the Republic of Indonesia qq Head of Regional Office of the National Land Agency of East Java Province qq Head of Land Office of Gresik Regency as Implementer of Land Procurement for Krian-Legundi-Bunder Toll Road Section. Located at: Jl. Dr. Wahidin Sudiro Husodo No. 234 Gresik - 61131, as Defendant II;

3. PT. WASKITA KARYA (Persero), Tbk located at: Jl. Jemursari Selatan II No. 2A-2B Jemur Wonosari, Wonocolo, Surabaya City East Java 60237, as the Defendant.

In addition, the Plaintiff also requested that the fair compensation value be Rp.4,000,000 (four million rupiah) per square meter, as well as requesting changes to the site plan and removal/shifting of the plan for the construction of the KLB toll road section from the portion middle or divide the Plaintiff's land into the western edge of the Plaintiff's land.

Whereas in the case of the decision of the Supreme Court of the Republic of Indonesia (MA RI) Number: 2597K/Pdt/2018 dated September 20, 2018 above, the Plaintiff (the Cassation Appellant) turned out to prefer taking the path of a public lawsuit with the act of violating the law (onrechtmatigedaad) article $1365 \mathrm{BW}$ rather than having to submit to the article the provisions of the special procedural law, although seen from the substance of the lawsuit is about the value of compensation that is clear according to article 38 of UU RI No. 2 of 2012 Jo. PERMA number 3 of 2016, the lawsuit model that should belong to the category of "The Complaint Appeals for Compensation".

So it can be said that the Complaint Appeals for Compensation is actually a new type of claim in the civil justice system, especially in land acquisition disputes for public interests. Indeed, if historically examined the background to the filing of the Act on Violation of the Law based on the description of the position case above, what 
should the Plaintiff suspect is expected to submit it because it has exceeded the expiration provisions 14 (fourteen) days from the deliberation on the determination of the value of compensation (vide case position: deliberation determination: dated September 21, 2016, the lawsuit was dated May $22,2017)$ so that the Plaintiff responded to this and dealt with it by submitting an ordinary Lawsuit, not "The Complaint Appeals for Compensation". The plaintiff was able to prove the fact that there was no evidence in the process of determining the value of compensation until a figure of Rp.1,042,196 (one million forty-two thousand one hundred ninety six rupiahs) per square meter was based on a deliberation on price between the Plaintiff and the Defendants, or in other words the determination of the price value is unilateral and it's unfair.

However, we have to be aware that it's not wrong if the lawsuit is filed not in the form of an appeal for compensation but rather in the format of the claim in general. The fact is that the Court is willing to accept and even examine and adjudicate where it should be if it does not enter the realm of competence, it is certain that from the beginning there will be a determination that the lawsuit cannot be accepted, whether the decision arises when the initial claim is filed or when the interlocutory decision regarding an exception.

Furthermore, the question is, does the Supreme Court's (MA RI) decision number: 2597K/PDT/2018 contradict with the provisions of procedural law as long as it is regulated by HIR/RIB or other legislation governing civil in general? Is it wrong if in the case above, the judge tends to have an opinion that the appeal for compensation is categorized as a lawsuit in violation of ordinary law? Do judges also have to be forced to follow certain patterns of understanding and interpretation of the law? Of course the answers to these questions must be objectively viewed from an academic perspective, theoretical aspects, and normative studies, so that the existence of principles as well as the norm that judges must not reject a case on the grounds that the law is absent or unclear, can still be applied.

The verdict of the cassation level (Mahkamah Agung RI) and the appeal level (Pengadilan Tinggi Jawa Timur) in the aforementioned case indeed mentioned that the first-level Court of Justice Panel
(Pengadilan Negeri Gresik) was wrong because it applied the civil procedure law in general. In fact, the panel of judges at Pengadilan Negeri Gresik granted the Plaintiff's claim with the consideration that the process of determining the price/value of land carried out unilaterally by the Defendants and not based on the result of deliberation agreement so that it was an illegal act and had harmed the Plaintiff's rights, which matter was considered/interpreted as an object of examination of a lawsuit in violation of the law, not an object of examination of "The Complaint Appeals for Compensation" in the Procurement of Land for Public Interests, so that is examined and argued by applying the procedural law in general. Therefore, it should be noted that the Judex Juris consideration of the Supreme Court (Mahkamah Agung) is purely a difference in interpretation of the application of law which incidentally becomes a legal product in the form of a court decision and has permanent legal force (in kracht van gewisjde). It's vulnerable that someday the interpretations of Judges from one another can be different, depending on the perceptions of each of their views which exactly stem from the same understanding of both the academic point of view and the same juridical normative study as well.

Then it can be interpreted that the formal civil law regulation specifically with "The Complaint Appeals for Compensation", normatively it turns out that it is absolutely unable to establish itself as a more specific provision/regulation, or in other words the application for objection to compensation in the acquisition of land for public use cannot yet plenaryly said as Lex Specialis of ordinary Lawsuit with the argument of unlawful acts. In fact this regulation does not change anything, even though it has been supported by the existence of RI Law (UU RI) number 2 of 2012 jo. PERMA number 3 of 2016, anyone including the Judge still has a gap and interpretation room to state whether a case filed with the Court includes a new type of lawsuit that is special in the form of a claim for compensation or remains categorized as a general lawsuit which is an act that violates the ordinary law. As long as the formal and material requirements for a lawsuit have been fulfilled, even though it overlaps with the land acquisition dispute for the public interests, judges must not refuse a case and may even grant a lawsuit if 
it is substantially the arguments of the lawsuit already have sufficient evidence based on the facts revealed at the court hearing.

The formal and material requirements of the lawsuit here are as explained by M. Yahya Harahap namely as required by article 118 paragraph (1) HIR/ Article 142 RBG and article 120 HIR, in brief can be detailed including the address must be addressed to the local PN fulfill the relative competence by being signed on the stamp by the Plaintiff himself or his attorney, given a date, listed the identity and address of the domicile of the parties, the lawsuit material containing the fundamental fundamentals or the arguments of the lawsuit (posita) consists of a legal basis (rechttelijke grond) and basic facts (feitelijke grond), and finally the petitum of a lawsuit or the principal claim of the plaintiff. ${ }^{2}$

Regarding the material of the lawsuit itself, namely by the argument of acts that violate the law, which becomes a spirit is a violation committed against the right of the Plaintiff so that he is harmed materially and immaterially. By citing Nicolai's opinion, Lukman Hakim ${ }^{3}$ gave an understanding of the concept of rights, he said that rights contain freedom to or not to take certain actions. In other literature also found several definitions of legal obligations coupled with the notion of legal rights. Sudikno Mertokusumo ${ }^{4}$ said that the right gives pleasure and freedom to the individual in carrying it out, while the obligation is a limitation and burden, so what stands out is the active aspect in the legal relationship, namely the right. So that back to the definition of rights above, it's not excessive if we relate it to the concept of unlawful conduct by trying to recall the decision of the Dutch Supreme Court (Arrest Hooge Raad) on 31 January 1919 on the case of Lindenbaum vs Cohen, which Van Bemmelen interpreted against the law in the Netherlands here is the understanding given by the Arrest. Hooge Raad argues that acts against the law must be interpreted as doing or not acting contrary to or violating: The subjective rights

\footnotetext{
${ }^{2}$ M. Yahya Harahap. (2013). Hukum Acara Perdata (Tentang Gugatan, Persidangan, Penyitaan, Pembuktian, dan Putusan Pengadilan). Jakarta: Sinar Grafika, h. 49-58.

${ }^{3}$ Lukman Hakim. (2010). Kedudukan Hukum Komisi Negara di Indonesia. Malang: Program Pascasarjana Universitas Brawijaya, h. 52.

${ }^{4}$ Sudikno Mertokusumo. (1999). Mengenal Hukum Suatu Pengantar. Yogyakarta: Liberty, h. 42.
}

of others; Actors' legal obligations; The principle of decency; and suitability in the community. ${ }^{5}$ More firmly R.Subekti ${ }^{6}$ states with the decision (Arrest) that the meaning of "onrechtmatige" is not only an act that violates the law or the rights of others, but also every act that is contrary to the "propriety that must be heeded in the community's association with the person or object of others".

Therefore, as is known in the case of the Supreme Court's (MA RI) decision number: 2597K/PDT/2018 above, if indeed from the beginning the Plaintiff felt that there was no longer an opportunity to file an appeal for compensation because the time had exceeded 14 (fourteen) days as required by RI Law (UU RI) number 2 of 2012 Jo. PERMA Number 3 of 2016, or even though the time is still within a period of 14 (fourteen days) though, but the Plaintiff is able to prove the argument of unlawful acts (their rights have been violated) by the Defendants and participated in the Defendant, resulting in material and immaterial losses to him, where that is more than enough as a condition for the filing of a general lawsuit to the District Court, certainly cannot be blamed when the plaintiff prefers to take the normal/ public lawsuit path rather than the Complaint claim for compensation so there is no need to submit to and be bound by the rules of civil procedural law specifically as regulated by RI Law (UU RI) number 2 of 2012 Jo. PERMA Number 3 of 2016. This means that the existence of RI Law number 2 of 2012 and PERMA Number 3 of 2016 have proven unable to guarantee the loss of dualism of understanding and law enforcement, especially for Judges, and in practice both are still equally applied so as to create new problems namely legal uncertainty and obstruction the accelerated national development program by the Government.

Derived from this problem so that lies the legal dogmatic issue that needs to be done research on it. Peter Mahmud Marzuki ${ }^{7}$ said that legal issues within the scope of legal dogmatics arise if: (1) parties who are litigants or who are involved in debates put forward different or even contradictory

5 J.M. Van Bemmelen. (1987). Hukum Pidana I-Hukum Pidana Material Bagian Umum. Bandung: Binacipta.

${ }^{6}$ Subekti. op.cit., h. 133.

${ }^{7}$ Peter Mahmud Marzuki. (2011). Penelitian Hukum Edisi Revisi. Jakarta: Kencana Prenada Media Group, h. 65. 
interpretations of the regulatory text due to the unclear rules themselves; (2) there is a legal vacuum; and (3) there are different interpretations of facts.

Therefore a deeper study of legal theory is needed so that in the future the main jurors of the Judges will have the right theoretical foundation so that it is expected to be more wise in addressing the dualism type of lawsuit and procedural law in land acquisition disputes for the public interests. In the end it is also hoped that harmony of perception and the unification of the application of formal civil law enforcement will be achieved regarding land acquisition disputes for the public interests, and double standards will not be occured anymore.

\section{FORMULATION OF LEGAL ISSUES}

Based on the background description of the problem above the formulations of relevant legal issues is will the special civil procedural law regarding Land Procurement disputes in the public interests automatically override the civil procedural law in general?

\section{RESEARCH METHODS}

\section{Typology of Research}

This research is a legal research with doctrinal research typology, where this research provides a systematic explanation of the legal rules governing a particular legal category, besides also analyzing the relationship between legal rules, explaining difficult and possible areas predict the future. ${ }^{8}$

\section{Problem Approach}

The approach used in this legal research is a case approach, a statute approach, a conceptual approach: a. Case Approach (case approach). This case approach is used to analyze the decisions of judges in this case the decision of the Supreme Court of the Republic of Indonesia (MA RI) Number: $2597 \mathrm{~K} / \mathrm{Pdt} / 2018$ dated September 20, 2018. Through this approach the judge's ratio decidendi will be analyzed in deciding the aquo case. The ratio decision analysis in this study is intended to find out the legal interpretation of the Supreme Court behind its considerations, including in this case the deci- sion ratio

\footnotetext{
${ }^{8}$ Lecture material notes by Dr. Sumedi, S.H., M.H.,
} Airlangga University Faculty of Law, September 21, 2018. regarding the application of special procedural law for handling cases or land acquisition disputes for development in the public interests.

b. Statute Approach. The legislative approach is absolutely used in this research as a foothold in answering the legal issues at hand. Legislation related to legal issues in this study are inventoried based on hierarchy and principles in legislation. Aside from the perspective of the form of the statutory regulations, of course in this research it is necessary to study the ontolological basis of the birth of the law, the philosophical basis of the law, and the legis ratio of related laws. In discussing legis ratios, aside from resting on an ontological basis and philosophical basis, it is also necessary to use the teaching of interpretation or interpretation or legal hermeutics.

c. Conceptual Approach. Legal issues in this study will also be analyzed using a conceptual approach. This approach is used to study and analyze the framework or conceptual framework and theoretical foundation in accordance with the objectives of this study. Therefore, it is necessary to put forward the concept of formal civil law, the concept of violating the law, the concept of a lawsuit and/or application, and the concept of land acquisition/procurement for development for public interests.

\section{ANALYSIS}

Whereas the focus of the discussion in this paper is litigation disputes in the procurement/acquisition of land for public interests, where the discussion is limited to just civil disputes with the argument of unlawful acts. Starting from the acquisition of land for public purposes can be achieved through land acquisition. Land acquisition for public purposes requires the approval of the right party. Because the rightful party is not willing to relinquish land rights or is willing but the price value is not as expected, but the agency that requires land (the Government) continues the land acquisition process for reasons of public interests, a dispute arises between the agencies that need land and authorized parties.

So what needs to be examined is the absolute competence, especially in the civil justice regime, the authority to adjudicate cases of unlawful acts (onrechtmatigedaad) absolutely becomes one of 
the duties and functions of the General Court (local District Court). Starting from here lies the discussion which then becomes the upstream issue regarding the dualism of the type of lawsuit and procedural law in land acquisition disputes in the public interests.

The study of the problem of dualism at one point is not sufficiently explored only at the level of legal dogmatics, but must be deepened regarding the concept of description in the perspective of theory and even legal philosophy, so that a prescription that is scientifically justifiable and its actualization relevant and relevant to the legal needs in the community. A description of the concept of a lawsuit in formal civil law both in terms of theory, substance and procedures has been described in the previous discussion, as well as a description of the concept of "appeal for compensation claim" has also been explained at length. In the aspect of legal theory, there is actually nothing wrong with the existence of the principle of legal preference and the principle (as well as the norm) that the judge cannot reject the case (ius curia novit), but in the development of judicial practice, especially regarding land acquisition disputes in the public interests, both not in line. In the end prescriptive study should be put forward as an alternative solution, the aim is none other than so that the application of legislation (applicable provisions) as a positive law can be realized by taking into account aspects of justice and legal usefulness.

The definition of prescription according to Kamus Besar Bahasa Indoensia (KBBI), ${ }^{9}$ Prescription/prescription/ $\mathrm{n}$ is what is required; provisions (instructions) regulations. Prescription is etymologically interpreted as a form of statement that is pre-descriptive in nature, that is, giving clues or provisions regarding what needs to take place or vice versa in relation to that simple object. In the doctrine and nature of the science of law, from a philosophical and legal theory perspective, it was explained by Philipus M. Hadjon ${ }^{10}$ that the science of law has a distinctive character, namely its normative, practical and prescriptive nature. Such character causes some circles who do not understand the personality of the science of law to begin to doubt the nature of the

\footnotetext{
${ }^{9}$ Kamus Besar Bahasa Indonesia (KBBI), op.cit.

${ }^{10}$ Philipus M. Hadjon and Tatiek Sri Djatmiati. (2005). Argumentasi Hukum. Yogyakarta: Gadjah Mada University Press, h. 1.
}

science of law. This doubt is due to the normative nature of law, not empirical science.

Legal science itself according to Gijssels and Van Hoecke ${ }^{11}$ is a science that is systematically and organized about the symptoms of law, the structure of power, norms, rights and obligations. So it is sufficient to say that law has characteristics as a prescriptive and applied science. As a prescriptive science, law studies the purpose of law, the values of justice, the validity of the rule of law, legal concepts and legal norms.

As a consideration for prescriptive studies, the author tries to quote the opinion of Urip Santoso ${ }^{12}$ who said, it is appropriate that land acquisition arrangements for public use are not in the form of a Republic of Indonesia Presidential Regulation, but in the form of a Law, namely Law of RI (UU RI) No. 2 of 2012 because in it regulates the rights and obligations of Indonesian citizens. Enactment of Law of RI (UU RI) No. 2 of 2012 in the acquisition of land for public use using the lex posteriori de rogat legi priori principle, which is a new law that eliminates or overrides the old law governing the same material. ${ }^{13}$ Based on this principle, Law of RI (UU RI) No. 2 of 2012 automatically nullifies or overrides Law of RI (UU RI) No. 20 of 1961 concerning Revocation of Rights to Land and the Items Above, as a legal basis for acquiring land for public purposes. According to Ida Nurlinda, ${ }^{14}$ that Law of RI (UU RI) No. 2 of 2012 both in terms of the law in the form of laws and the material content that contains rules regarding land valuation and the existence of a process of public consultation as a process of dialogic communication, indeed looks better than the previous similar rules. Whereas land acquisition for public interests on the one hand is

11 Jan Gijssels and Mark van Hoecke. (1982). What is Rechtsteorie?. Antwerrpen: Kluwer, Rechtwetenschappen, h. 8.

${ }^{12}$ Urip Santoso. "Penyelesaian Sengketa Dalam Pengadaan Tanah Untuk Kepentingan Umum”. PERSPEKTIF. Fakultas Hukum Universitas Wijaya Kusuma Surabaya, Vol 21 No. 3 Edisi September Tahun 2016, h. 188-198.

13 Hartono Hadisoeprapto. (1982). Pengantar Hukum Indonesia. Yogyakarta: Liberty, h. 30.

${ }^{14}$ Ida Nurlinda. "Penyelesaian Sengketa dan/atau Konflik Dalam Pengadaan Tanah Untuk Kepentingan Umum”. Makalah Seminar Nasional Pengadaan Tanah Untuk Kepentingan Umum Pasca Berlakunya Undang-Undang No. 2 Tahun 2012. Surabaya: Program Pascasarjana Universitas Airlangga. 27 November 2012, h. 8 . 
for the sake of creating national development which in the end is also for the achievement of the noble ideals of a country that is promoting public welfare.

At this point the author finally tries to address with a thought discourse describing which concepts are more relevant if used for the benefit and law enforcement based on rational legal arguments. So based on legal theory with the principle of legal certainty, justice and legal benefit, then by not reducing the existence of the principle of ius curia novit, the author believes that the principle of norm preference in land acquisition disputes for the public interests needs to be prioritized with the note that there must be a follow up arrangement against the current legal provisions. This is in accordance with the classical method, namely the public interests must take precedence over the interestss of individuals, bearing in mind that the dimensions of land acquisition for the public interests reach the social aspects and general welfare of a nation, whereas the basis for individual land rights championed through conventional law only has the dimension of individual rights which are individual in nature very private.

However, further regulation of Law of RI (UU RI) No. 2 of 2012 which the author means here is not by deregulating the regulations and regulations contained in the law. As is well known several regulations and beleids related to Land Procurement for Public Interests are still in the hierarchy of statutory regulations as referred to in Law of RI (UU RI) No. 12 of 2011 concerning the formation of legislation has been prepared, including the Republic of Indonesia Presidential Regulation (Perpres RI) No. 148 of 2015 concerning the Fourth Amendment to Perpres RI Number 71 of 2012 concerning the Implementation of Land Procurement for Development in the Public Interests, PERMA Number 3 of 2016 concerning Procedures Submission of objection and Depository of Indemnity to the District Court in the Procurement of Land for Development for Public Interests, and Regulation of the Minister of Agrarian Affairs and Spatial Planning/Head of BPN RI (Permen Agraria dan Tata Ruang/Kepala BPN RI) No. 6 of 2015 concerning amendment to the Regulation of the Minister of Agrarian Affairs and Spatial Planning/ Head of BPN RI (Permen Agrarai dan Tata Ruang/ Kepala BPN RI) No. 6 of 2015 concerning Technical
Guidelines for Implementing Land Acquisition. Regarding these regulations and regulations it is not equal to HIR/RIB and BW which are in the hierarchy, including the scope of the law, so it is not possible to be included in the comparison of norm preference principles with law of RI (UU RI) No. 2 of 2012.

Technically, the author would like to convey that it is necessary to do the delegislation of Law of RI (UU RI) No. 2 of 2012 as soon as possible or at least with the issuance of Perppu. In order to immediately revise Law of RI (UU RI) No. 2 of 2012, especially the addition of provisions/norms relating to the actualization of the principle of special norm preferences regarding disputes over the value of land into a norm (article), so that the existence of rules regarding Land Procurement Disputes in the Public Interests that exists At present (Law of RI No. 12 of 2012 and the rules below it) can firmly become a lex specialis from the provisions of BW and HIR/RIB as lex generali. The norm must be clear and firm so that with this type of lawsuit and the applicable procedural law must be subject to the provisions of Law of RI (UU RI) No. 12 of 2012 and the rules below it without the need for other interpretations or debate.

This is surely expected to be able to contribute to the development of Legal Studies, especially in the field of justice for civil procedural law relating to Land Procurement for development in the public interests. This theoretical contribution is specifically to clarify the legal and real juridical character of land acquisition arrangements for development in the public interests with a strong theoretical foundation. This paper is also expected to contribute to the practice of law in Indonesia, especially for stakeholders seeking justice in disputes over land acquisition issues for development in the public interests within the framework of legal certainty and usefulness.

\section{CLOSING SECTION}

\section{The Conclusion}

From the formulation of the following problem, the discussion above, 2 (two) conclusions can be taken:

1. Whereas the special civil procedure law regarding land acquisition disputes in the public interests as regulated in Law of RI (UU RI) No. 
2 of 2012 jo. PERMA No. 3 of 2016 concerning Procedures for Submitting Objection and Safekeeping of Indemnity to the District Court in Land Procurement for Development for Public Interests, will not necessarily override general civil procedural law as regulated in $\mathrm{BW}$ (material civil law) and HIR/RIB ( formal civil law) even though it is based on the principle of norm preference, it is caused on the other hand there are also principles at the same time ius curia novit norms, i.e. Judges/Courts must not refuse to examine, try and decide on a case submitted under the pretext that the law is not there is or is unclear, but it is obligatory to examine and try it.

2. That to get around the harmonization of thoughts so that dualism types of lawsuits and procedural law do not occur in land acquisition disputes in the public interests, an appropriate theoretical foundation is needed. In the aspect of legal theory, there is actually nothing wrong with the existence of the principle of legal preference and the principle (as well as the norm) that the judge cannot reject the case (ius curia novit), but in the development of judicial practice, especially regarding land acquisition disputes for public interests, both not in line. In the end prescriptive study should be put forward as an alternative solution, the aim is none other than so that the application of legislation (applicable provisions) as a positive law can be realized by taking into account aspects of justice and legal usefulness. For this reason, the writer/author tries to describe which concepts which are more relevant are used for the benefit and law enforcement based on rational legal arguments. So based on legal theory with the principle of legal certainty, justice and legal benefit, by not reducing the existence of the principle of ius curia novit, the author believes that the principle of norm preference in land acquisition disputes for public interests needs to be prioritized with the note that there must be a follow-up arrangement for current legal provisions. This is in accordance with the classical method, namely the public interests must take precedence over the interestss of individuals, bearing in mind that the dimensions of land acquisition for the public interests reach the social aspects and general welfare of a nation, whereas the basis for individual land rights championed through conventional law only has the dimension of individual rights which are individual in nature very private.

\section{Recommendation}

It is necessary to hold a delegislation of Law of RI (UU RI) No. 2 of 2012 or at least with the issuance of Perppu. In order to immediately revise Law No. 2 of 2012, especially the addition of provisions/norms relating to the actualization of the principle of special norm preferences regarding disputes over the value of land into a norm (article), so that the existence of rules regarding Land Procurement Disputes in the Public Interests that exists At present (RI Law No.12 of 2012 and the rules below it) can firmly become a lex specialis from the provisions of $\mathrm{BW}$ and HIR/ $\mathrm{RBg}$ as lex generali. The norm must be clear and firm so that the type of lawsuit and applicable procedural law must also be subject to the provisions of Law of RI (UU RI) No.12 of 2012 and the rules below it without the need for other interpretations or debate.

\section{BIBLIOGRAPHY}

\section{Law Regulation:}

Undang-Undang RI Nomor 2 Tahun 2012 tentang Pengadaan Tanah Bagi Pembangunan Untuk Kepentingan Umum (Lembaran Negara Republik Indonesia Tahun 2012 Nomor 22, Tambahan Lembaran Negara 5280).

Undang-Undang RI Nomor 48 Tahun 2009 tentang Perubahan Atas Undang-undang RI Nomor 4 Tahun 2004 tentang Kekuasaan Kehakiman (Lembaran Negara Republik Indonesia Tahun 2009 Nomor 157, Tambahan Lembaran Negara Republik Indonesia Nomor 5076).

Undang-Undang RI Nomor 3 Tahun 2009 tentang Perubahan Kedua Atas Undang-undang RI Nomor 14 Tahun 1985 tentang Mahkamah Agung (Lembaran Negara Republik Indonesia Tahun 2009 Nomor 3, Tambahan Lembaran Negara Nomor 4958).

H.I.R./R.I.B (Het Herzein Indonesisch Reglement Stb.1848 No. 16 Jo Stb. 1941 No. 44).

R.Bg. (Rechtsreglement voor de Buitengewesten,

Staatsblad 1927 Nomor 227).

$\mathrm{Rv}$ (Reglement op de rechtsvordering, Staatsblad 1847 Nomor 52 juncto 1849 Nomor 63). 
R.O. (Reglement of de rechterlijke organisatie in het beleid der justitie in Indonesia, Staatblad 1847 Nomor 23).

B.W. (Burgerlijk wetboek/Kitab Undang-Undang Hukum Perdata/Kitab Undang-Undang Hukum Sipil) yang dikodifikasi pada tanggal 1 Mei 1848.

Peraturan Mahkamah Agung (PERMA) RI Nomor 3 Tahun 2016 tentang Tata Cara Pengajuan Keberatan dan Penitipan Ganti Keugian ke Pengadilan Negeri dalam Pengadaan Tanah Bagi Pembangunan untuk Kepentingan Umum.

Peraturan Menteri Agraria dan Tata Ruang/Kepala BPN RI No. 6 Tahun 2015 tentang Perubahan Peraturan Menteri Agraria dan Tata Ruang/ Kepala BPN RI No. 6 Tahun 2015 tentang Juknis Pelaksanaan Pengadaan Tanah.

\section{Journal:}

Urip Santoso. "Penyelesaian Sengketa Dalam Pengadaan Tanah Untuk Kepentingan Umum". PERSPEKTIF. Fakultas Hukum Universitas Wijaya Kusuma Surabaya, Vol 21 No. 3 Edisi September Tahun 2016, h. 188-198.

\section{Paper:}

Hartono Hadisoeprapto. (1982). Pengantar Hukum Indonesia. Yogyakarta: Liberty.

Ida Nurlinda. "Penyelesaian Sengketa dan/atau Konflik Dalam Pengadaan Tanah Untuk Kepentingan Umum". Makalah Seminar
Nasional Pengadaan Tanah Untuk Kepentingan Umum Pasca Berlakunya Undang-Undang No. 2 Tahun 2012. Surabaya: Program Pascasarjana Universitas Airlangga. 27 November 2012.

J.M. Van Bemmelen. (1987). Hukum Pidana I - Hukum Pidana Material Bagian Umum. Bandung: Binacipta.

Jan Gijssels and Mark van Hoecke. (1982). What is Rechtsteorie?. Antwerrpen: Kluwer, Rechtwetenschappen.

Kamus Besar Bahasa Indoensia (KBBI).

Lecture material notes by Dr. Sumedi, S.H., M.H., Airlangga University Faculty of Law, September $21,2018$.

Lukman Hakim. (2010). Kedudukan Hukum Komisi Negara di Indonesia. Malang: Program Pascasarjana Universitas Brawijaya.

M. Yahya Harahap. (2013). Hukum Acara Perdata (Tentang Gugatan, Persidangan, Penyitaan, Pembuktian, dan Putusan Pengadilan). Jakarta: Sinar Grafika.

Peter Mahmud Marzuki. (2011). Penelitian Hukum Edisi Revisi. Jakarta: Kencana Prenada Media Group.

Philipus M. Hadjon and Tatiek Sri Djatmiati. (2005). Argumentasi Hukum. Yogyakarta: Gadjah Mada University Press.

Subekti. (1996). Pokok-Pokok Hukum Perdata. Jakarta: PT Intermasa.

Sudikno Mertokusumo. (1999). Mengenal Hukum Suatu Pengantar. Yogyakarta: Liberty. 